Original Article

\title{
Small mammals in the diet of Barn Owls (Tyto furcata) in an urban area in Rio de Janeiro state, Brazil, with a new record of the dwarf mouse opossum (Cryptonanus)
}

\author{
Pequenos mamíferos na dieta da coruja-suindara (Tyto furcata) em uma região urbana do \\ estado do Rio de Janeiro, Brasil, com um novo registro da catita do gênero Cryptonanus
}

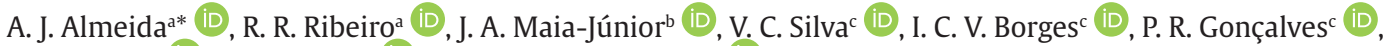 \\ K. S. Rangel ${ }^{\text {(iD }}$, H. V. R. Dias ${ }^{a}$ (iD) and A. B. F. R. Godinho ${ }^{a}$ (iD \\ a Universidade Estadual do Norte Fluminense Darcy Ribeiro - UENF, Centro de Ciências e Tecnologias Agropecuárias, Campos dos Goytacazes, RJ, Brasil

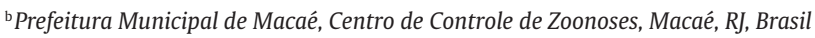 \\ ' Universidade Federal do Rio de Janeiro - UFRJ, Núcleo em Ecologia e Desenvolvimento Socioambiental de Macaé, Macaé, RJ, Brasil
}

\begin{abstract}
Several studies emphasize the use of owl pellets in small mammal inventories in natural areas harboring high richness of rare species, but few Brazilian Atlantic forest localities have been surveyed by this method. The present study documents the species composition and abundance of small mammals in the diet of Tyto furcata in an urban area of the municipality of Campos dos Goytacazes, Rio de Janeiro, Brazil, remarking on a new record of the dwarf mouse opossum genus Cryptonanus in the Atlantic forest. We analyzed 265 pellets regurgitated by a pair of T. furcata from November 2016 to September 2017 found in a nesting box. Analysis of the samples enabled finding a total of 596 individuals of four small mammal species. Mus musculus was predominant among the prey items (98.3\%), while the native rodents Necromys lasiurus (1.3\%) and Holochilus brasiliensis (0,17\%) were much rarer. A single specimen of Cryptonanus sp. was identified among the diet items based on distinctive dental characters. The identification of this genus in the present study represents the second record in the state of Rio de Janeiro, and the sixth in the Atlantic Forest biome, suggesting that this marsupial occupies a wider ecological and biogeographic range. The present study underscores the relevance of owl pellets for small mammal surveys, even in urban and highly disturbed areas.
\end{abstract}

Keywords: mammals, Cryptonanus, Atlantic Forest.

\begin{abstract}
Resumo
Vários estudos enfatizam o uso de pelotas de coruja em inventários de pequenos mamíferos em áreas naturais com elevada riqueza de espécies raras, mas poucas localidades da Mata Atlântica brasileira têm sido inventariadas por esse método. O presente estudo documenta a composição de espécies e abundância de pequenos mamíferos na dieta de Tyto furcata em uma área urbana do município de Campos dos Goytacazes, Rio de Janeiro, Brasil, discutindo a relevância de um novo registro de um raro marsupial do gênero Cryptonanus na Mata Atlântica. Foram analisadas 265 pelotas regurgitadas por um casal de T. furcata entre novembro de 2016 e setembro de 2017, encontradas abaixo de uma caixa de nidificação. A análise das amostras permitiu encontrar o total de 596 indivíduos de quatro espécies pequenas de mamíferos. O roedor exótico Mus musculus foi predominante entre os itens alimentares (98,3\%), enquanto os roedores nativos Necromys lasiurus (1,3\%) e Holochilus brasiliensis ( $0,17 \%)$ foram bem mais raros. Um único espécime de Cryptonanus sp. foi identificado entre os itens com base em caracteres dentários. A identificação desse gênero no presente estudo representa o segundo registro no estado do Rio de Janeiro e o sexto no bioma Mata Atlântica, sugerindo que este marsupial ocupa uma ampla faixa ecológica e biogeográfica. O presente estudo destaca a relevância dos pellets de coruja para pesquisas com pequenos mamíferos, mesmo em áreas urbanas e altamente perturbadas.
\end{abstract}

Palavras-chave: mamíferos, Cryptonanus, Mata Atlântica.

\section{Introduction}

Owls are members of the Strigiformes, an order with two families, the Strigidae and Tytonidae (Robert Ridgway, 1914). This latter is solely represented in Brazil by Tyto furcata (Temminck, 1827) (Menq, 2013).
The American barn owl, Tyto furcata, has great importance for the biological control of rural and urban pests of public health interest, as it preys on species that are harmful to human health and agriculture, like invasive

*e-mail: jardim@uenf.br

Received: May 9, 2020 - Accepted: September 2, 2020

This is an Open Access article distributed under the terms of the Creative Commons Attribution License, which permits unrestricted use, distribution, and reproduction in any medium, provided the original work is properly cited. 
rodents and insects (Roda, 2006; Lekunze et al., 2001; Kross et al., 2016).

Since the main prey of Tyto furcata are small mammals, especially rodents and marsupials, the diet of these owls reflects the composition and abundance of local prey species (Jaksic et al., 1982; Ebensperger et al., 1991; Clark-Junior and Bunck, 1991; Love et al., 2000). Due to their efficient predation, these owls often include in their diet species that are rare and infrequently recorded by conventional mammal inventorying techniques (Bonvicino and Bezerra, 2003; Formoso et al., 2010; Lemos et al., 2015; Stumpp et al., 2016). Therefore, the study of owl pellets has great relevance to assess the local diversity of small mammals and document the presence of rare species, besides allowing evaluation of the possible function of this bird of prey in the control of exotic rodent species. However, owl pellet studies are still rare in the Brazilian Atlantic forest, especially in Rio de Janeiro state (Romano et al., 2020)

In this context, the general objective of the present study was to document the composition of mammalian species in the diet of a Tyto furcata couple in an urban area of the municipality of Campos dos Goytacazes, in the northern region of the state of Rio de Janeiro, Brazil. The monitoring of the pair's diet also provided a rare record of the dwarf mouse opossum (Cryptonanus) among the preyed items in addition to native and exotic rodents. The biogeographic and ecological implications of these records are discussed.

\section{Material and Methods}

The study was approved by the Committee on Ethical Use of Animals of Norte Fluminense Darcy Ribeiro State University (UENF) under protocol no. 366.

\subsection{Study area}

We analyzed 265 pellets regurgitated by a pair of American barn owls (Tyto furcata), naturally nesting in the yard of a residence located in an urban area of the municipality of Campos dos Goytacazes, Rio de Janeiro (geographic coordinates: -21.7778040, -41.3309670) from November 2016 to September 2017, located at Atlantic Forest area (Figure 1). The climate regime is governed by the tropical climate with dry winter season. In autumn and winter, incursions of the Polar Atlantic air mass result in the frequent passage of SE weather fronts. Annual rainfall in this region ranges between 900 and 1100 with average annual temperature of $24^{\circ} \mathrm{C}$. To better characterize the area probably used daily by owls, we delimited a 2-km radius buffer area around the nesting site and calculated the area occupied by each landscape feature. This radius was based on information provided by Taylor (1994) on the daily movements of Barn owls to foraging sites. The landscape features were obtained from Rezende et al. (2018), which analyzed land cover using Rapid Eye imagery from 2013 at $5 \mathrm{~m}$ resolution. All GIS computations were performed on QGIS 4.02.

The owls were first observed for seven days, resting during daylight hours at the top of a metal ladder attached to the wall, and leaving to hunt at night. On the seventh day after they had left to hunt (at around 8:00 p.m.), a wooden box measuring $52 \times 31.5 \times 37 \mathrm{~cm}$ (length, width, height) (Figure 2A) was installed, containing a perch, at a height of 5 meters on a metal support attached on the outside wall of the residence (Figure 2B). At the same time, an analog infrared CFTV security camera $(3.6 \mathrm{~mm}$, 750 lines, Al-mdir720d Dome Alive ${ }^{\circledR}$ ) was installed on another wall directly across from the opening of the nesting box (Figure 2C). After the installation of the camera and box, the owls quickly accommodated themselves in the artificial nest (Figure 2D). The structure and camera

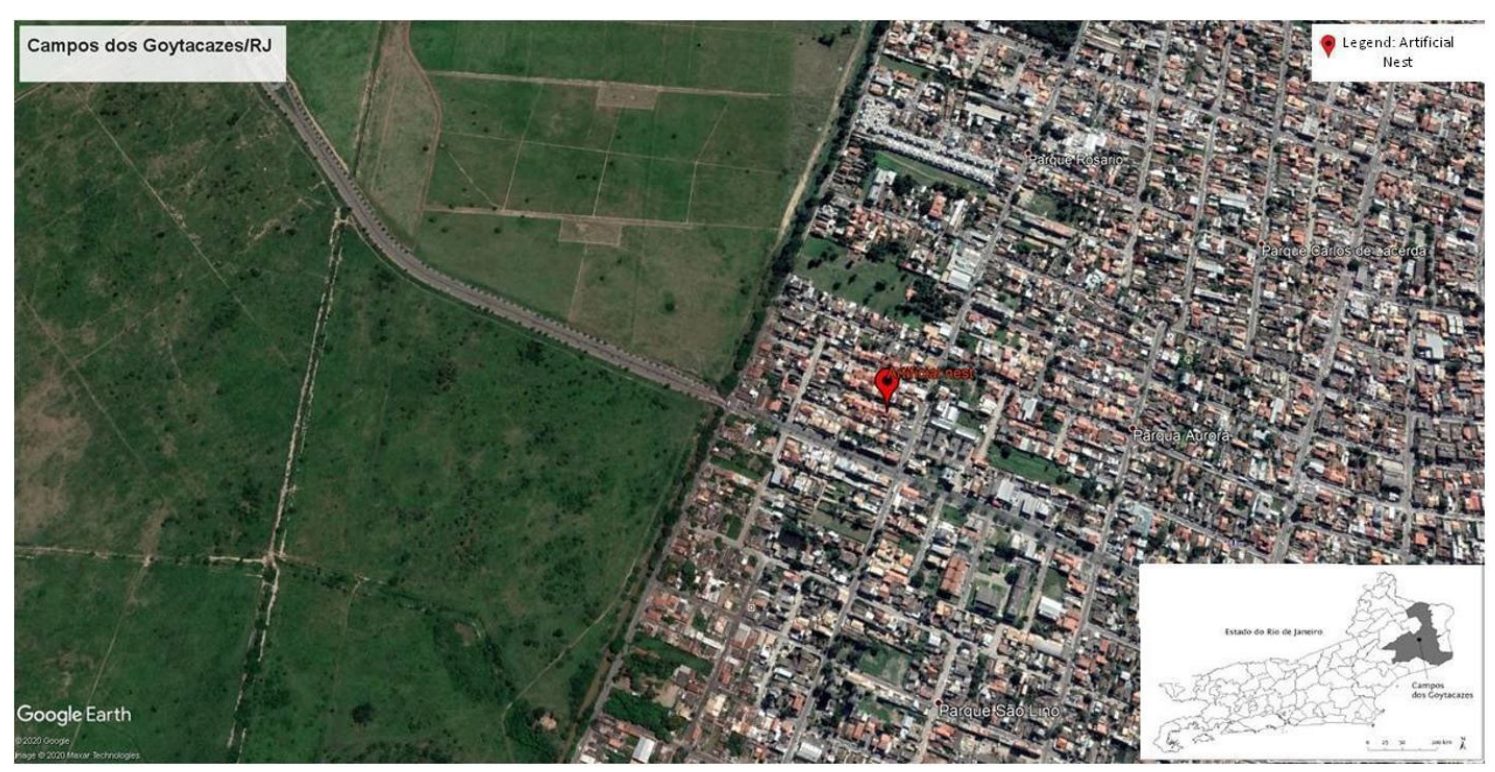

Figure 1. Satellite image showing nesting site of the T. furcata couple and the surrounding area in Campos dos Goytacazes, Rio de Janeiro. Adapted from Google Earth®. 


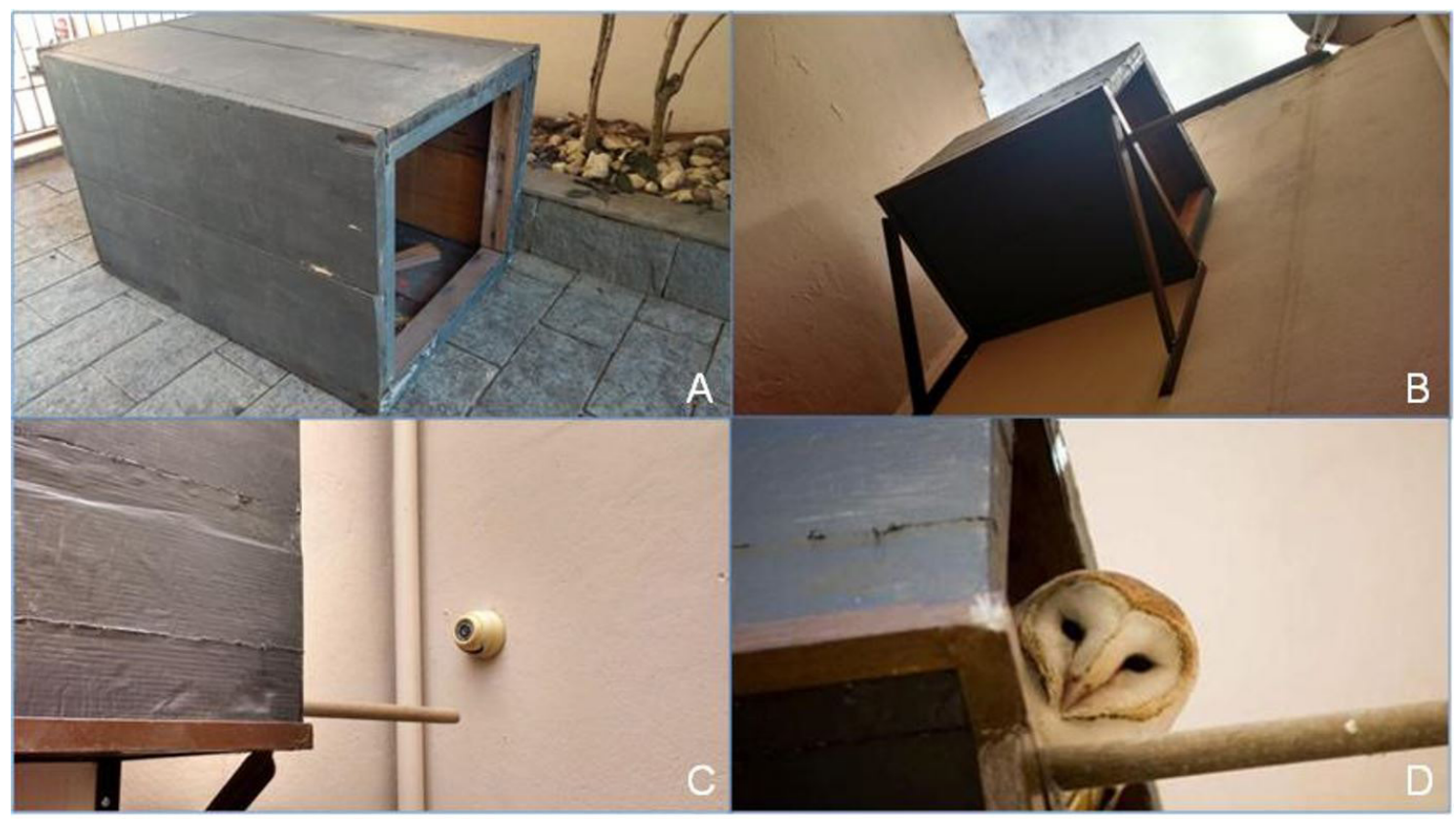

Figure 2. Installations for accommodation of the Tyto furcata pair outside a residence in an urban area of Campos dos Goytacazes, RJ. (A) Waterproofed wooden box, measuring $52 \times 31.5$ x $37 \mathrm{~cm}$ (length x width x height); (B) Box with perch; and (C) Camera positioned and focused on the artificial nest and its surroundings; (D) Immediate acceptance by the Tyto furcata pair of the artificial nest after its installation. Campos dos Goytacazes, RJ.

installed enabled monitoring the owl couple's daily routine, including egg laying and care for the chicks.

\subsection{Analysis of pellets}

Owl pellets are composed of indigestible materials from the birds' prey and are easily found near their habitual resting places. We collected all the pellets found under the nesting box daily throughout the period in which the owls remained in place. They were placed in individual plastic bags identified with number and date, and stored under refrigeration at a temperature of $8^{\circ} \mathrm{C}$ in a closed container for subsequent laboratory analysis.

The material from each bag was individually weighed with a high-precision analytic balance (Shimadzu $₫$ model $\mathrm{BL} 3200 \mathrm{H}$ ) and the major and minor diameter of each pellet was measured with a Mitutoyo ${ }^{\circledR}$ model CD-6" CSX-B digital pachymeter, the accuracy of caliper \pm 0.02 . The pellets were first moistened in a container with water to facilitate separation of the items contained in each one. Then each pellet was placed in a Petri dish and examined using tweezers and dissection needles. The material from each pellet was analyzed separately, one by one (Figure $3 \mathrm{~A}$ ). The separated material was then cleaned with tweezers, small brushes and a toothbrush, to enable detailed evaluation of their structures, separating the craniums and mandibles for morphological identification of the prey animals eaten by the owls (Figure 3B).

Owing to the fragmentary state of most skulls, the most reliable structures for taxonomic identification of rodents and marsupials consisted in molars. The identification of specimens was then based on diagnostic dental characters proposed by the taxonomic literature on Neotropical
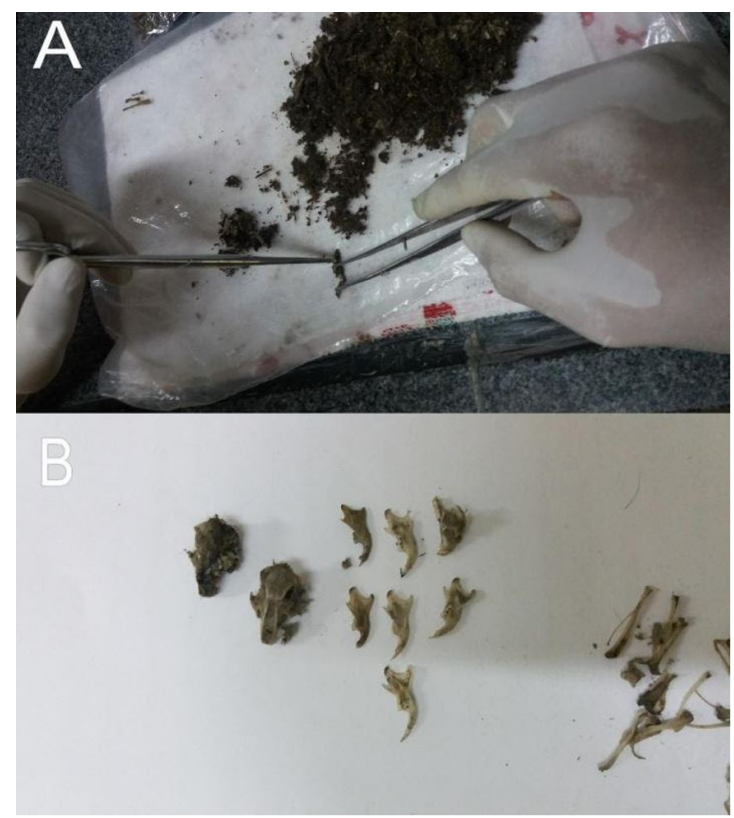

Figure 3. Manipulation and identification of the pellets collected below the artificial nest of the Tyto furcata pair. (A) Separation of bone material; (B) Selection of craniums and mandibles for morphological identification.

marsupials and rodents (Gonçalves et al., 2015; Percequillo, 2006; Pires et al., 2016; Stutz et al., 2020; Voss, 1991; Voss et al., 2005; Voss and Jansa, 2009), and also based on comparisons with voucher specimens in the mammalian collection (NPM) of the Institute of Biodiversity and Sustainability, Federal University of Rio de Janeiro 
(NUPEM/UFRJ). The number of preys was estimated by counting the most numerous individual bone element (e.g., left mandible) found in the sorted pellet material (Lemos et al., 2015). The analysis of the pellets was carried out with the collaboration of the staff members of the Animal Anatomy Section of the Laboratory for Animal Morphology and Pathology (LMPA/CCTA/UENF) and the Integrated Laboratory of Zoology at NUPEM/UFRJ.

The specimens examined for comparisons were: Gracilinanus microtarsus, Brazil: Espirito Santo state, Domingos Martins, NPM 224-226, 234, 235; Rio de Janeiro state, Macaé, NPM 1681, 1682, Reserva Biológica União, NPM 1841, 1845; Minas Gerais state, Cataguases, NPM 1761; Monodelphis iheringi: Brazil, Rio de Janeiro state: Parque Natural Municipal do Atalaia, Macaé, NPM 010, 034-036, 045, 883, 884, 1010.

\section{Results}

The most common landscape features in the buffer area (1251 ha) around the nesting site were edifications (54.6\% of the area) and pastures (43.3\%). Forest fragments comprised only $2 \%$ of the buffer area, while flooded or humid areas accounted for less than $0.1 \%$.

Table 1. Seasonality of the prey individuals collected and identified in pellets of Tyto furcata. Campos dos Goytacazes, RJ.

\begin{tabular}{lcccc}
\hline Táxon & Spring & Summer & Fall & Winter \\
\hline Birds & - & - & - & 02 \\
$\begin{array}{l}\text { Holochilus } \\
\text { brasiliensis }\end{array}$ & - & - & - & 01 \\
$\begin{array}{l}\text { Mus } \\
\text { musculus }\end{array}$ & 14 & 25 & 170 & 372 \\
$\begin{array}{l}\text { Necromys } \\
\text { lasiurus }\end{array}$ & 02 & - & 05 & 01 \\
$\begin{array}{l}\text { Cryptonanus } \\
\text { sp. }\end{array}$ & - & - & - & 01 \\
$\begin{array}{l}\text { Inconclusive } \\
\text { (Rodents) }\end{array}$ & - & - & - & 03 \\
Total & 16 & 25 & 175 & 380 \\
\hline
\end{tabular}

We identified 596 individuals (Table 1 ) from one species of marsupial, the dwarf mouse opossum Cryptonanus sp., and from three species of rodents, the house mouse Mus musculus, the pixuna field mouse Necromys lasiurus, and the marsh-rat Holochilus brasiliensis (Figures 4 and 5). Total frequency of prey items was higher during the winter (Table 1). The average weight of the pellets was $5.71 \mathrm{~g}$, ranging from $1.33 \mathrm{~g}$ to $20.17 \mathrm{~g}$. The average major diameter was $36.44 \mathrm{~mm}$ (20.02 to $62.50 \mathrm{~mm}$ ) and the minor diameter was $26.55 \mathrm{~mm}$ ( 18.85 to $38.72 \mathrm{~mm}$ ). Mus musculus was by far the most abundant prey, accounting for $98.3 \%(n=586)$ of all individuals preyed. Necromys lasirus accounted for $1.3 \%(n=8)$ of all preyed individuals, while Holochilus brasiliensis and Cryptonanus sp. accounted each for only $0,2 \%(n=1)$ of the prey.

Rodents were represented by partial skulls (lacking basicranium and occipital) and mandibles, but Cryptonanus sp. was solely represented by one mandible (right and left rami) bearing two premolars and four molars. Therefore, the taxonomic identification of Cryptonanus was based on dental traits, because mandibular characters are less informative in comparisons with other similarly sized and potentially sympatric mouse opossum genera, such as Gracilinanus and Monodelphis. Cryptonanus (Figure 4A) and Gracilinanus (Figure 4B) can be clearly distinguished from Monodelphis (Figure 4C) by the presence of a prominent entoconid on lower molars (Voss and Jansa, 2009). In Monodelphis the entoconid is reduced to a low rim, never forming a prominent cusp (Figure 4C). These three genera also differ in lower molar size, with Gracilinanus generally presenting larger molars than Cryptonanus and Monodelphis. The length of m1-m4 in a sample Gracilinanus microtarsus from Rio de Janeiro state (see 2.2 Analysis of pellets) varies from 6.12 to $6.44 \mathrm{~mm}$, while specimens of Cryptonanus agricolai from Piauí state studied by Motta et al. (2019) varied from 5.4 to $5.6 \mathrm{~mm}$, and specimens of a sample of Monodelphis iheringi from Rio de Janeiro state varied from 5.47 to $5.84 \mathrm{~mm}$. The specimen examined in this study presented small molars, with a m1-m4 length of $5.59 \mathrm{~mm}$, which combined with the prominent entoconids confirms its identity as a representative of the genus Cryptonanus. Identification beyond genus level was not possible given the lack of upper molars and cranial structures informative for species identification (Voss et al., 2005).
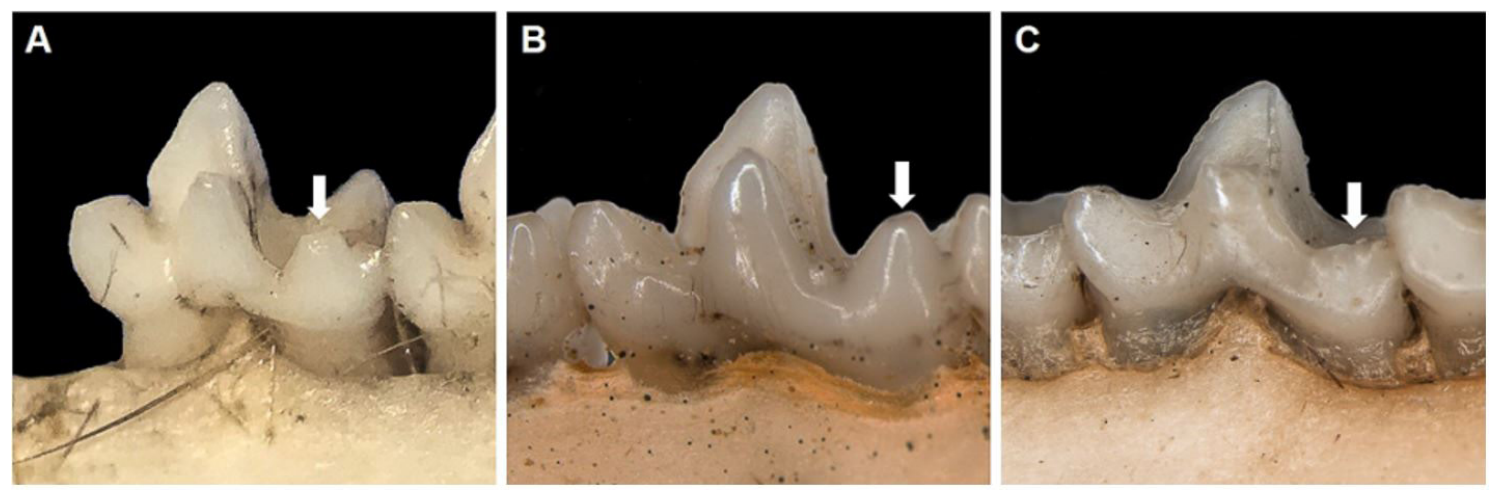

Figure 4. Labial views of the second lower molars of the didelphid marsupials (A) Cryptonanus sp. (this study, Campos dos Goytacazes, Rio de Janeiro state), (B) Gracilinanus microtarsus (NPM 1682, Macaé, Rio de Janeiro state), and (C) Monodelphis iheringi (NPM 1010, Macaé, Rio de Janeiro state), showing the variation in the entoconid size. 


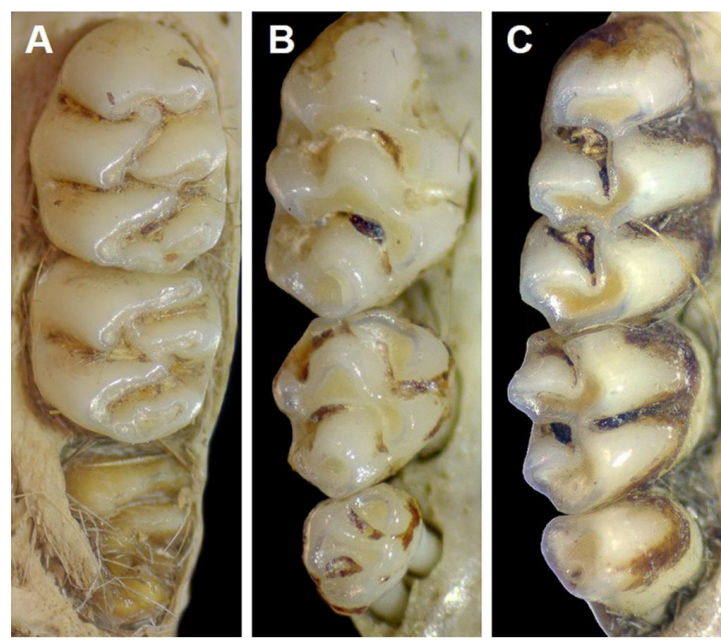

Figure 5. Occlusal views fo the upper molar row of the rodents (A) Holochilus brasiliensis, (B) Mus musculus, and (C) Necromys lasiurus recorded in owl pellets at Campos dos Goytacazes, Rio de Janeiro state.

The Holochilus brasiliensis record consisted in a young specimen with M3 not ecloded (Figure 5A), and its identification was based on the slightly alternating cusps, unexpanded paracones, and the presence of mesolophlike structures on M1- M2 (Gonçalves et al., 2015). The numerous skull and mandible fragments of Mus musculus were easily identified by their upper and lower molars with a tri-serial cusp alignment and smaller size (Figure 5B). On the other hand, specimens of Necromys lasiurus (Figure 5C) could be recognized by the undivided procingulum of M1 lacking a anteromedian flexus, lack of mesolophs on M1 and M2, and small cylindrical M3 (Pardiñas et al., 2015).

\section{Discussion}

Several studies have emphasized the use of owl pellets in small mammal inventories in natural areas harboring high richness of rare species seldomly sampled by conventional trapping methods (Bonvicino and Bezerra, 2003; Heisler et al., 2015; Lemos et al., 2015; Stutz et al., 2020; Torre et al., 2004). Our study highlights that owl pellets are useful to record rare mammals also in urban and highly disturbed areas dominated by invasive species. The record of the rare Cryptonanus sp. documented here is noteworthy as this is one of the most poorly represented didelphid marsupial genera in scientific collections. Consequently, there are many gaps in the distribution and taxonomy of this genus in South America. Most collecting localities of Cryptonanus are located in open biomes in South America, such as the Cerrado, Chaco, Pampas and Caatinga (Voss et al., 2005). However, recent records have extended its distribution to the Atlantic forest of Southeastern Brazil, suggesting a wider ecological and biogeographical range for this genus (Umetsu and Pardini, 2007; Delciellos et al., 2016; Guerra and Costa, 2019).
The record of Cryptonanus reported here indicates that this marsupial might also occur in highly disturbed areas, with reduced forest cover. Assuming Barn owls might use an area of $\sim 1500$ ha around the nest to forage on a daily basis (Taylor, 1994), the area of probable provenance of the Cryptonanus specimen is mostly dominated by urban and cattle grazing activities, with few scattered forest patches that together account for only 253.6 ha. Even if Barn owls occasionally fly over larger distances to forage, the nearest protected areas (Parque Estadual do Desengano, Parque Estadual Lagoa do Açú, and RPPN Fazenda Caruara) are more than $20 \mathrm{~km}$ away from the nesting site. Therefore, the present record suggests that Cryptonanus species might indeed inhabit small forest fragments immersed in an urban/rural matrix. This higher tolerance of Cryptonanus to antropogenic habitats is in accordance with Umetsu and Pardini (2007) suggestion that this genus might prefer disturbed over well-preserved Atlantic forest areas.

The few Atlantic forest records of Cryptonanus comprise localities located in the states of São Paulo (Cotia and Ibiúna: Umetsu and Pardini, 2007) Rio de Janeiro (Serras das Araras: Delciellos et al. 2016) and Espirito Santo (Pinheiros: Guerra and Costa, 2019), in Southeastern Brazil, and in the state of Pernambuco (São Lourenço da Mata: Souza et al., 2010), in Northeastern Brazil. The present study thus represents the second record of this genus in Rio de Janeiro state, and the sixth record in the Atlantic forest. Delciellos et al. (2016) originally identified the record from Serra das Araras, in Rio de Janeiro state, as Cryptonanus sp. owing to the moderate genetic distance (3.2\% of mitochondrial cytochrome $b$ sequence divergence) of their specimen (MZUSP 35409) in relation to a specimen from Piauí state. Posteriorly, most authors (Dias et al., 2016; Guerra and Costa, 2019; Teta and Díaz-Nieto, 2019) inadvertently considered Rio de Janeiro and/or Piauí genetically analyzed specimens as Cryptonanus agricolai, without mentioning morphological and genetic criteria for identifying these specimens as conspecifics. Following the proposal of these authors, the specimen from Campos dos Goytacazes could more likely represent $C$. agricolai. However, the molecular identification of the Rio de Janeiro specimen reported by Delciellos et al. (2016) is further complicated by the fact that none of the sequenced specimens identified as $C$. agricolai were in fact compared with the holotype of this nominal form. Therefore, until further evidence is presented favoring the conspecificity among Atlantic forest specimens and the holotype of $C$. agricolai, we maintain the identity of the specimens from Rio de Janeiro state as Cryptonanus sp.

In addition to the rare record of Cryptonanus, the records of the marsh rat Holochilus brasiliensis and the pixuna field mouse Necromys lasiurus in the urban area are also relevant. Holochilus brasiliensis and Necromys lasiurus are rare in the Atlantic forest of Rio de Janeiro state, and are more commonly associated to grassy formations. In the state of Rio de Janeiro, these species are more common in areas with greater dominance of pastures, as is the case of Campos dos Goytacazes (Gonçalves et al., 2015; Lemos et al., 2015; De Oliveira Santos et al., 2018). The presence of $H$. brasiliensis and $N$. lasiurus among the food items thus suggests the owls are sporadically hunting in rural areas with abandoned or less managed pastures near the nesting site. 
Despite the noteworthy records of native species, most native small mammals found in nearby restingas and coastal forests (Geise and Astúa, 2009; Pessôa et al., 2010) and already documented in owl pellets (Lemos et al., 2015) were not present in the diet items analyzed herein. The diet sample of small mammals reported here is thus representative of an urban area with low species richness and high dominance of the invasive Mus musculus. The association of M. musculus with human dwellings indicates the owls' foraging territory mainly consisted of urban and peri-urban areas. However, other diet studies of T. furcata in wild areas with smaller human influence have also reported $M$. musculus to be among the most common prey species (Messias et al., 2013; Lemos et al., 2015; Köhler et al., 2019).

In localities of Rio Grande do Sul state, Mus musculus accounted for more than $80 \%$ of the mammals preyed by Barn owls, despite the presence of a rich assemblage of native species in the diet items (Scheibler and Christoff, 2007; Stutz et al., 2020). Likewise, in the Parque Nacional da Restinga de Jurubatiba, Mus musculus continued to be one of the most preyed rodents, although presenting lower relative abundance (39.6\%) compared to the Rio Grande do Sul localities (Lemos et al., 2015). Therefore, it is possible that the greater frequency of M. musculus among the diet items reflects, besides the use of urban areas for hunting, indicates a greater facility of owls in capturing this exotic rodent (Köhler et al., 2019). Romano et al. (2020) also suggested that Barn owls might specialize in preying smaller rodents, which in the present case would be represented by Mus musculus. Testing these hypotheses might be difficult without required complimentary trapping experiments. Nevertheless, wherever in urban or wild areas, Barn owls seem to exert significant predation pressure on Mus musculus populations.

In summary, the present study underscored the relevance of owl pellets for small mammal surveys, even in urban and highly disturbed areas, documenting the occurrence of a rare didelphid marsupial in the Brazilian Atlantic forest, and highlighting the importance of Barn owls in the predation of invasive species.

\section{References}

BONVICINO, C. and BEZERRA, A., 2003. Use of regurgitated pellets of barn owl (Tyto alba) for inventorying small mammals in the Cerrado of Central Brazil. Studies on Neotropical Fauna and Environment, vol. 38, no. 1, pp. 1-5. http://dx.doi.org/10.1076/ snfe.38.1.1.14030.

CLARK-JUNIOR, D.R. and BUNCK, C.M., 1991. Trends in North American small mammals found in common barn-owl (Tyto alba) dietary studies. Canadian Journal of Zoology, vol. 69, no. 12, pp. 3093-3102. http://dx.doi.org/10.1139/z91-435.

DE OLIVEIRA SANTOS, F., TEIXEIRA, B.R., PASSOS CORDEIRO, J.L., DE SOUSA, R.H.A., LUCIO, C.D.S., GONÇALVES, P.R., LEMOS, H., DE OLIVEIRA, R.C., FERNANDES, J., CAVALCANTI, G.R., DE LEMOS, E.R.S. and D'ANDREA, P.S., 2018. Expansion of the range of Necromys lasiurus (Lund, 1841) into open areas of the Atlantic Forest biome in Rio de Janeiro state, Brazil, and the role of the species as a host of the hantavirus. Acta Tropica, vol. 188, no. 3, pp. 195-205. http:// dx.doi.org/10.1016/j.actatropica.2018.08.026. PMid:30149024.
DELCIELLOS, A.C., VIANA, M.C., AGUIEIRAS, M., CHIARADIA, F. and GASPAR, D.D.A., 2016. First record of genus Cryptonanus (Didelphimorphia) in the state of Rio de Janeiro, Brazil. Check List, vol. 12, no. 1, pp. 1-7. http://dx.doi.org/10.15560/12.1.1827.

DIAS, D., FONSECA, C., CHEREM, J.J., GRAIPEL, M.E., CHRISTOFF, A.U. and ROCHA, R.G., 2016. New records of Cryptonanus guahybae (Tate, 1931) in southern Brazil inferred from molecular and morphological data. Mammalia, vol. 80, no. 2, pp. 211-219. http://dx.doi.org/10.1515/mammalia-2014-0071.

EBENSPERGER, L.A., MELLA, J.E. and SIMONETTI, J.A., 1991. Trophicniche relationships among Galictis cuja, Dusicyon culpaeus, and Tyto alba in Central Chile. Journal of Mammalogy, vol. 72, no. 4, pp. 820-823. http://dx.doi.org/10.2307/1381849.

FORMOSO, A.E., SAUTHIER, D.E.U. and PARDIÑAS, U.F.J., 2010. Mammalia, Rodentia, Sigmodontinae, Holochilus brasiliensis (Desmarest, 1819): distribution extension. Check List, vol. 6, no. 2, pp. 195-197. http://dx.doi.org/10.15560/6.2.195.

GEISE, L. and ASTÚA, D., 2009. Distribution extension and sympatric occurrence of Gracilinanus agilis and G. microtarsus (Didelphimorphia, Didelphidae), with cytogenetic notes. Biota Neotropica, vol. 9, no. 4, pp. 269-276. http://dx.doi.org/10.1590/ S1676-06032009000400030.

GONÇALVES, P.R., TETA, P. and BONVICINO, C.R., 2015. Genus Holochilus Brandt, 1835. In: J.L. PATTON, U. F. PARDIÑAS and G. D'ELÍA, eds. Mammals of South America. Chicago: The University of Chicago Press, vol. 2, pp. 325-335.

GUERRA, E.B. and COSTA, L.P., 2019. Range extension of Cryptonanus agricolai (Didelphimorphia, Didelphidae) and first record in the Atlantic forest core. bioRxiv. 1-21. http://dx.doi. org/10.1101/774752.

HEISLER, L.M., SOMERS, C.M. and POULIN, R.G., 2015. Owl pellets: a more effective alternative to conventional trapping for broad-scale studies of small mammal communities. Methods in Ecology and Evolution, vol. 7, no. 1, pp. 96-103. http://dx.doi. org/10.1111/2041-210X.12454.

JAKSIC, F.M., SEIB, R.L. and HERRERA, C.M., 1982. Predation by the barn owl (Tyto alba) in mediterranean habitats of Chile, Spain, and California: a comparative approach. American Midland Naturalist, vol. 107, no. 1, pp. 151-162. http://dx.doi. org/10.2307/2425196.

KÖHLER, B., GUIMARÃES, L.J. and SRBEK-ARAUJO, A.C., 2019. Diet of the American Barn Owl, Tyto furcata (Temminck, 1827), in a Tabuleiro Atlantic Forest remmant in Southeastern Brazil. The Wilson Journal of Ornithology, vol. 131, no. 1, pp. 111-118. http://dx.doi.org/10.1676/17-31.

KROSS, S.M., BOURBOUR, R.P. and MARTINICO, B.C., 2016. Agricultural land use, barn owl diet, and vertebrate pest control implications. Agriculture, Ecosystems \& Environment, vol. 223, pp. 167-174. http://dx.doi.org/10.1016/j.agee.2016.03.002.

LEKUNZE, M.L., EZEALOR, U.A. and AKEN'OVA, T., 2001. Prey groups in the pellets of the barn owl Tyto alba alba (Scopoli) in the Nigerian savanna. African Journal of Ecology, vol. 39, no. 1, pp. 38-44. http://dx.doi.org/10.1046/j.1365-2028.2001.00274.x.

LEMOS, H.M., SILVA, C.A.O., PATIU, F.M. and GONÇALVES, P.R., 2015. Barn Owl pellets (Aves: Tyto furcata) reveal a higher mammalian richness in the Restinga de Jurubatiba National Park, Southeastern Brazil. Biota Neotropica, vol. 15, no. 2, pp. 1-9. http://dx.doi.org/10.1590/1676-06032015012114.

LOVE, R.A., WEBON, C., GLUE, D.E., HARRIS, S. and HARRIS, S., 2000. Changes in the food of British barn owls (Tyto alba) between 1974 and 1997. Mammal Review, vol. 30, no. 2, pp. 107-129. http://dx.doi.org/10.1046/j.1365-2907.2000.00060.x. 
MENQ, W., 2013 [viewed 17 May 2019]. Corujas brasileiras Aves de Rapina Brasil [online]. Available from http://www. avesderapinabrasil.com/arquivo/artigos/Corujas_brasileiras.pdf

MESSIAS, G., FARIA, M. and PASSAMANI, M., 2013. Dieta da Corujada-Igreja (Tyto alba, Scopoli, 1769) do sul de Minas Gerais e sua relação com disponibilidade de presas. Revista Brasileira de Zoociências, vol. 15, no. 1, pp. 247-252.

MOTTA, F.A., HADLER, P., CHEREM, J.J. and RIBEIRO, A.M., 2019. A marsupial assemblage (Mammalia, didelphimorphia) from the quaternary of the Serra da Capivara, State of Piauí, Brazil. Revista Brasileira de Paleontologia, vol. 22, no. 3, pp. 225-239. http://dx.doi.org/10.4072/rbp.2019.3.05.

PARDIÑAS, U.F.J., TETA, P., ORTIZ, P.E., JAYAT, J.P. and SALAZARBRAVO, J., 2015. Necromys. In: J.L. PATTON, U.F.J. PARDIÑAS and G. D'ELÍA, eds. Mammals of South America. Chicago: The University of Chicago Press, vol. 2, pp. 232-247.

PERCEQUILLO, A.R., 2006. Guia para a nomenclatura e padronização da descrição da dentição nos roedores sigmodontíneos. Boletim da Sociedade Brasileira de Mastozoologia, vol. 47, pp. 5-11.

PESSÔA, L.M., TAVARES, W.C. and GONÇALVES, P.R., 2010. Mamíferos das restingas do macrocompartimento litorâneo da Bacia de Campos, Rio de Janeiro. In: L.M. PESSOA, W.C. TAVARES and S. SICILIANO, eds. Mamíferos de Restingas e Manguezais do Brasil. Rio de Janeiro: Sociedade Brasileira de Mastozoologia/Museu Nacional, pp. 95-125.

PIRES, C., GUDINHO, F. and WEKSLER, M., 2016. Morfologia dentária de gêneros de Sigmodontinae (Rodentia: Cricetidae) com ocorrência no Cerrado brasileiro. Boletim da Sociedade Brasielira de Mastozoologia, vol. 75, pp. 1-32.

REZENDE, C.L., SCARANO, F.R., ASSAD, E.D., JOLY, C.A., METZGER, J.P., STRASSBURG, B.B.N., TABARELLI, M., FONSECA, G.A. and MITTERMEIER, R.A., 2018. From hotspot to hopespot: an opportunity for the Brazilian Atlantic Forest. Perspectives in Ecology and Conservation, vol. 16, no. 4, pp. 208-214. http:// dx.doi.org/10.1016/j.pecon.2018.10.002.

RODA, S.A., 2006. Dieta de Tyto alba na Estação Ecológica do Tapacurá, Pernambuco, Brasil. Revista Brasileira de Ornitologia, vol. 14 , no. 4, pp. 449-452.

ROMANO, A., SÉCHAUD, R. and ROULIN, A., 2020. Global biogeographical patterns in the diet of a cosmopolitan avian predator.Journal of Biogeography, vol. 47, no. 7, pp. 1-15. http:// dx.doi.org/10.1111/jbi.13829,

SCHEIBLER, D.R. and CHRISTOFF, A.U., 2007. Habitat associations of small mammals in southern Brazil and use of regurgitated pellets of birds of prey for inventorying a local fauna. Brazilian Journal of Biology = Revista Brasileira de Biologia, vol. 67, no. 4, pp. 619-625. http://dx.doi.org/10.1590/S1519-69842007000400005. PMid:18278312.
SOUZA, D.P., ASFORA, P.H., LIRA, T.C. and ASTÚA, D., 2010. Small mammals in Barn Owl (Tyto alba - Aves, Strigiformes) pellets from Northeastern Brazil, with new records of Gracilinanus and Cryptonanus (Didelphimorphia, Didelphidae). Mammalian Biology, vol. 75, no. 4, pp. 370-374. http://dx.doi.org/10.1016/j. mambio.2009.08.003.

STUMPP, R., NASCIMENTO-COSTA, M.C., BORONI, N.L., DUARTE, T.D.S. and LESSA, G. 2016. Contributions to the knowledge of small mammals (Mammalia) from northwestern Minas Gerais, Brazil. In: Instituto Nacional da Mata Atlântica. Boletim do Museu de Biologia Mello Leitão (Nova Série). Santa Teresa: Instituto Nacional da Mata Atlântica, pp. 1-21.

STUTZ, N.S., HADLER, P., CHEREM, J.J. and PARDIÑAS, U.F.J., 2020. Small mammal diversity in Semi-deciduous Seasonal Forest of the southernmost Brazilian Pampa: the importance of owl pellets for rapid inventories in human-changing ecosystems. Papéis Avulsos de Zoologia, vol. 60, pp. 1-12. http://dx.doi. org/10.11606/1807-0205/2020.60.25.

TAYLOR, I., 1994. Barn Owls: predator-prey relationships and conservation. 2nd ed. Cambridge: Cambridge University Press. 304 p.

TETA, P. and DÍAZ-NIETO, J.F., 2019. How integrative taxonomy can save a species from extinction: the supposedly extinct mouse opossum Cryptonanus ignitus (Diaz, Flores and Barquez, 2000) is a synonym of the living $C$. chacoensis (Tate, 1931). Mammalian Biology, vol. 96, pp. 73-80. http://dx.doi. org/10.1016/j.mambio.2019.04.004.

TORRE, I., ARRIZABALAGA, A. and FLAQUER, C., 2004. Three methods for assessing richness and composition of small mammal communities. Journal of Mammalogy, vol. 85, no. 3, pp. 524-530. http://dx.doi.org/10.1644/BJK-112.

UMETSU, F. and PARDINI, R., 2007. Small mammals in a mosaic of forest remnants and anthropogenic habitats - Evaluating matrix quality in an Atlantic forest landscape. Landscape Ecology, vol. 22, no. 4, pp. 517-530. http://dx.doi.org/10.1007/ s10980-006-9041-y.

VOSS, R.S. and JANSA, S.A., 2009. Phylogenetic relationships and classification of Didelphid marsupials, an extant radiation of New World Metatherian Mammals. Bulletin of the American Museum of Natural History, vol. 322, pp. 1-177. http://dx.doi. org/10.1206/322.1.

VOSS, R.S., 1991 [viewed 9 May 2020]. An introduction to the Neotropical muroid rodent genus Zygodontomys. Bulletin of the American Museum of Natural History [online], no. 210, pp. 1-113. Available from: http://digitallibrary.amnh.org/handle/2246/905

VOSS, R.S., LUNDE, D.P. and JANSA, S.A., 2005. On the contents of Gracilinanus Gardner \& Creighton, 1989, with the description of a previously unrecognized clade of small didelphid marsupials. American Museum Novitates, vol. 3482, pp. 1-34. http://dx.doi. org/10.1206/0003-0082(2005)482[0001:OTCOGG]2.0.CO;2. 